\title{
Analisis kebutuhan anak usia dasar dan Implikasinya dalam penyelenggaraan pendidikan
}

Dian Andesta Bujuri

Prodi PGMI Program Pascasarjana

Fakultas Ilmu Tarbiyah dan Keguruan

UIN Sunan Kalijaga

Email:dianandesta819@gmail.com

\begin{abstract}
Abstrak
Manusia, sebagai makhluk hidup dan makhluk sosial, memiliki kebutuhan dasar yang mesti terpenuhi agar dapat bertahan hidup dan memperoleh kehidupan yang nyaman, senang dan sejahtera, tak terkecuali anak usia dasar. Kebutuhan anak usia dasar (6-12 tahun) berbeda dengan kebutuhan anak remaja dan orang dewasa. Penelitian ini bertujuan untuk menganalisis kebutuhan anak usia dasar dan implikasinya terhadap penyelenggaraan pendidikan. Metode penelitian yang digunakan adalah metode penelitian kualitatif jenis library research. Berdasarkan hasil analisis, kebutuhan anak usia dasar meliputi enam aspek yaitu, Pertama kebutuhan fisiologis seperti makanan, minuman, wahana permainan dan sebagainya. Kedua, kebutuhan perlindungan dan rasa aman seperti lingkungan yang asri, aman dan damai. Ketiga, kebutuhan akan rasa kasih sayang dan perhatian. Keempat, kebutuhan akan penghargaan atas segala tindakan atau prestasi. Kelima, kebutuhan aktualisasi diri seperti menunjukan kemampuan (ability) atau bakat (talent) yang dimiliki. Keenam yaitu kebutuhan akan rasa sukses. Setiap individu dan tingkatan usia anak memiliki level kebutuhan yang berbeda-beda, dikarenakan adanya perbedaan faktor usia, fisik, psikologi, keturunan dan lingkungan. Kebutuhan anak usia dasar sangat berkaitan dengan proses pendidikan anak. Pada usia dasar, anak memiliki kemampuan berifkir dan bergerak yang masih terbatas. Anak juga memiliki sifat yang egois, keras kepala, manja dan sensitif yang masih sangat tinggi. Hematnya, sebagai pihak eksternal, orang tua, guru maupun orang dewasa mesti memahami tingkat kebutuhan dan karakter anak, supaya tidak terjadi kesalahan dalam mendidik dan mengajar dalam rangka membentuk pribadi anak yang beriman, cerdas dan berkarakter.
\end{abstract}

Kata Kunci : Kebutuhan Anak Usia Dasar dan Penyelenggaraan Pendidikan.

\section{A. Pendahuluan}

Manusia merupakan mahkluk hidup yang terdapat di bumi yang memiliki kelebihan paling sempurna baik dari struktur fisik dan keistimewaan akal untuk mengkatualisasikan diri yang tidak dimiliki oleh makhluk lainnya. Secara alamiah, manusia memiliki kodrat yang hakiki dalam dirinya sejak ia dilahirkan dan membawa potensi-potensi (sifat dan bakat) yang bersifat genetik. Pada dasarnya, untuk menjalani kehidupannya, manusia sebagai makhluk yang bernyawa dan hidup berdampingan dengan makhluk hidup lainnya, tentu memiliki kebutuhan-kebutuhan wajib dan mendasar yang mesti terpenuhi dan tidak bisa hindarkan. Kebutuhan-kebutuhan itu beragam, mulai dari kebutuhan yang diperlukan untuk memenuhi kebutuhan fisiologis (fisik) seperti makan dan minum maupun yang berkaitan dengan kepribadian seperti keamanan, kasih sayang, harga diri, kesuksesan dan lain sebagainya. 
Sebagaimana menurut Maslow, variasi kebutuhan manusia tersusun dalam bentuk hierarki atau berjenjang. Setiap jenjang kebutuhan dapat dipenuhi hanya kalau jenjang sebelumnya telah (relatif) terpuaskan. Jenjang itu meliputi kebutuhan pada tingkatan yang lebih rendah menuju kebutuhan yang tingkatannya lebih tinggi (Alwisol, 2009). Menurut hemat penulis, Maslow menekankan bahwa mulanya manusia akan memenuhi kebutuhan fisiknya terlebih dahulu seperti makan dan minum sebelum memenuhi kebutuhan batinnya. Bagaimana manusia akan memenuhi kebutuhan rasa nyaman dan kasih sayang apabila kebutuhan fisik yang sejatinya penggerak seluruh bagian tubuh belum terpenuhi. Artinya, kebutuhan rasa nyaman dan kasih sayang akan terwujud apabila manusia sudah memenuhi kebutuhan fisiknya.

Hakikatnya, dalam kondisi normal, kebutuhan-kebutuhan manusia bersifat sama meskipun setiap pribadinya memiliki perbedaan dari segi fisik, sikap dan perilaku. Namun, pada kondisi tertentu apabila ada suatu kebutuhan tidak terpenuhi akan berdampak pada perubahan sikap dan perilaku pada pribadi seseorang. Fakta itu mengindikasikan bahwa manusia memiliki kebutuhan-kebutuhan tertentu yang tidak bisa di rekayasa atau dipaksakan apabila itu bertentangan dengan dirinya. Hal itu menunjukan bahwa kebutuhan mempunyai peran dan pengaruh penting dalam menentukan tingkah laku manusia. Manusia akan mendapat beban, merasa memiliki kekurangan dan tidak nyaman apabila kebutuhannya tidak terpenuhi.

Setiap tahap proses perkembangannya, manusia memiliki kebutuhan yang tidak sama pada setiap tingkatannya. Seperti, pada tahap anak-anak usia dasar, usia remaja, usia dewasa dan usia tua. Perbedaan-perbedaan kebutuhan itu bisa dari jenis atau hanya memiliki perbedaan dari segi ukuran dan levelnya. Pada anak usia dasar, kebutuhankebutuhan yang harus dipenuhi sangat bergantung terhadap orang lain (orang tua, kakak, guru, teman dan lain sebagainya) karena mereka belum mampu memenuhi kebutuhannya secara personal. Misalnya, untuk memenuhi kebutuhan fisiologis, kecil kemungkinan anak-anak harus bekerja. Anak usia dasar memiliki keterbatasan dalam berfikir, bergerak, dan bekerja layaknya seperti orang dewasa.

Selanjutnya, menurut Oswald Kroch pada fase anak usia dasar umumnya mengalami keguncangan jiwa yang dimanifestasikan dalam bentuk sifat trotz atau sifat keras kepala, suka membantah, menentang orang lain terutama terhadap orang tuanya (Desmita, 2017). Pendapat Oswald Kroch sesuai dengan fakta pada umumnya, anak usia dasar cenderung memiliki sifat manja, sensisitif dan egois. Tidak jarang kita temukan kesalahan orang tua dalam mendidik anak dan banyak terjadi kekerasan terhadap anak di dunia pendidikan. Kesalahan tersebut dapat berpengaruh terhadap pribadi anak. Sebagaimana menurut gardner (2011) "kreatifitas bisa menurun karena adanya kesalahan dalam mendidik anak" (Astuti, Megawangi \& Sari, 2013, 365). Salah satu faktor penyebab peristiwa tersebut rentan terjadi yaitu ketika orang tua atau seorang pendidik tidak memahami tahap perkembangan anak dalam memenuhi kebutuhan-kebutuhan yang sesuai dengan fasenya.

Oleh sebab itu, setiap orang tua, kakak, guru atau orang yang lebih dewasa sepatutnya mengetahui dan paham terkait dengan perkembangan anak serta kebutuhankebutuhan yang harus terpenuhi. Sehingga tidak akan terjadi suatu kebingungan atau ketidaktahuan yang dapat berakibat fatal terhadap fisik dan pribadi anak. Berdasarkan latar belakang tersebut, penulis tertarik melakukan penelitian untuk mengkaji dan menganalisis secara teoritis maupun empiris terkait dengan kebutuhan manusia yang dalam hal ini difokuskan pada anak usia dasar (6-12 tahun) dan bagaimana implikasinya dalam pendidikan. 


\section{B. Metode Penelitian}

Metode penelitian yang digunakan dalam penelitian ini yaitu metode peneletian kualitatif. Metode penelitian kualitatif adalah "metode penelitian yang digunakan untuk meneliti pada kondisi obyek alamiah, dimana peneliti adalah sebagai intrumen kunci" (Sugiyono, 2009, 1). Berdasarkan objek kajian, penelitian ini termasuk penelitian yang bersifat litere atau kepustakaan (library research). library research adalah suatu peneltian yang dilakukan dengan cara mengumpulkan data, informasi dan berbagai macam data-data lainnya yang terdapat dalam kepustakaan (Joko, 1991). Sehingga, pada penelitian ini, pembasannya didasarkan pada teori-teori kebutuhan dasar manusia khususnya tentang kebutuhan kebutuhan anak usia dasar dan implikasinya teradap pendidikan. Sumber data yang digunakan dalam penelitian ini yaitu buku, jurnal, artikel, dan karya ilmiah lainnya yang relevan terhadap objek kajian pada penelitian ini. Teknik pengumpulan data pada penelitian ini adalah dokumentasi. Selanjutnya, untuk mengolah dan menganalisis data, penulis menggunakan metode content analysis yaitu sebuah analisis terhadap kandungan isi yang berfokus pada interpretasi dari sebuah karya.

\section{Hasil dan Pembahasan \\ 1. Teori Kebutuhan Dasar Manusia}

Seperti yang sudah dipaparkan pada bab sebelumnya, manusia mempunyai kebutuhan-kebutuhan yang wajib dan mendasar untuk dipenuhi sebagai upaya untuk dapat bertahan hidup dan mewujudkan kehidupan yang nyaman, senang dan sejahtera. Kebutuhan merupakan sesuatu yang sangat dibutuhkan oleh manusia untuk dapat mencapai kesejahteraan, sehingga bila kebutuhan tersebut ada yang tidak atau belum terpenuhi maka pastilah manusia akan merasa kurang sejahtera (Heru, 2017). Selaras dengan pendapat Afrooz (1966) "kebutuhan (need) adalah A natural requirement which should be satisfied in order to secure a better organic compatibility" (Desmita, 2017, 59). Artinya adalah kebutuhan merupakan suatu keperluan/syarat alamiah yang harus terpenuhi untuk menjamin kebaikan, kesenangan dan kesejahteraan seseorang sesuai dengan keinginan dirinya. Sedangkan Chaplin (2002) mendifinisikan need (kebutuhan) sebagai satu subtansi seluler yang harus dimiliki oleh organisme, agar organisme tersebut tetap sehat. Lebih umum Chaplin menyebutkan bahwa "kebutuhan adalah segala kekurangan dan ketiadaan atau ketidaksempurnaan yang dirasakan seseorang, sehingga merusak kesejahteraan" (Desmita, 2017, 59). Kebutuhankebutuhan tersebut dapat diperoleh secara pribadi maupun dari pihak luar (manusia dan alam).

Senada dengan pengertian di atas, penulis memahami bahwa kebutuhan merupakan sesuatu yang sangat subtansial yang sudah menjadi bagian dari diri manusia sejak dilahirkan untuk memenuhi kesesuaian hidup yang normal hingga meninggal dunia. Semua manusia dilahirkan dengan kebutuhan-kebutuhan instinktif yaitu suatu kebutuhan-kebutuhan universal yang mendorong manusia tumbuh dan berkembang, untuk mengaktualisasikan dirinya dan untuk menjadikan semuanya sejauh kemampuan dasar yang dimiliki (Mif, 2008). Jadi, jelas bahwa setiap individu membawa potensi pertumbuhan, kondisi fisik dan kesehatan yang berbeda sejak dilahirkan. Sehingga, disamping kondisi sosial atau lingkungan, potensi bawaan juga memberikan pengaruh yang signifikan dan dapat menentukan keberhasilan dari pada aktualisasi diri seseorang. Akan tetapi manusia memiliki kecenderungan untuk mencapai kebutuhan-kebutuhan yang penuh makna dalam hidupnya dan memberikan suatu kepuasaan yang membuat dirinya merasa nyaman dan tentram. 
Secara umum, kebutuhan biasanya akan muncul ketika seseorang merasa memiliki kekurangan dalam dirinya dan sesegara mungkin berusaha untuk memenuhi kekurangan tersebut. Kondisi demikian, apabila kekurangan yang dirasakan itu tidak segera tertutupi maka akan mengganggu kenyaman dirinya, bahkan akan berdampak lebih dari itu, misalnya stres dan frustasi yang dapat merusak kesejahteraan hidup. Sehingga, pada kondisi tertentu suatu kebutuhan tidak bisa terelakan dari manusia. Manusia akan terus bergerak dan berusaha dengan berbagai macam cara untuk memenuhi kebutuhannya serta melakukan berbagai macam tindakan, meskipun tak jarang tindakan yang dilakukan bernilai negatif bahkan berbuah petaka.

Maslow mengemukakan bahwa "manusia dimotivasikan oleh sejumlah kebutuhan dasar yang bersifat sama untuk seluruh spesies, tidak berubah, dan berasal dari sumber genetis atau naluriah" (Mif, 2008, 191). Kebutuhan-kebutuhan yang mendominasi pribadi seseorang tidak selalu berkaitan dengan hal fisiologis (fisik) melainkan juga berkaitan dengan kebutuhan psikologis (kejiwaan). Penulis memahami bahwa kebutuhan-kebutuhan tersebut merupakan aspek yang mesti terpenuhi dalam keberlangsungan hidup manusia itu sendiri. Selanjutnya, disisi lain, manusia juga memiliki kelemahan yang sewaktu-waktu dapat dengan mudahnya terkendalikan dan terpengaruhi oleh lingkungannya. Kendati sewaktu-waktu kebutuhan sudah terpenuhi, namun masih belum merasa terpuaskan bahkan akan melahirkan tuntutan-tuntutan dari kebutuhan yang lainnya. Hal demikian akan terus terjadi dalam diri setiap individu sepanjang kehidupannya, selagi hawa nafsu mendominasi pribadi seseorang.

Berdasarkan penjelasan-penjelasan di atas, penulis berkesimpulan bahwa pada hakikatnya seluruh makhluk hidup khususnya manusia pasti mempunyai kebutuhankebutuhan, baik yang bersifat wajib dan mendasar (oksigen, makan, minum dan lainlain) maupun yang bersifat kebutuhan perkembangan atau pertumbuhan (kreatif, mental, realisasi diri, dan lain-lain) yang hanya dibutuhkan oleh manusia diantara makhluk hidup lainnya. Kebutuhan wajib atau kebutuhan dasar sudah menjadi kebutuhan pokok yang alamiah sejak manusia berada dalam kandungan hingga terlahir di dunia. Sehingga, jelas bahwa kebutuhan tersebut dapat dikatakan sebagai sarat wajib bagi manusia untuk hidup dan bertahan hidup. Sebagai contoh, ketika seseorang merasa haus dan lapar maka yang terpikirkan adalah bagaimana untuk mendapatkan makanan dan minuman secepat mungkin ketimbang memikirkan kebutuhan yang lain.

Akan tetapi dalam hal ini penulis berbeda pendapat dengan Maslow, menurut penulis setiap kebutuhan tidak selamanya muncul lebih awal dari kebutuhan tertingi ke terendah atau sebaliknya. Misalnya, pada kondisi tertentu seseorang cenderung mengutamakan kebutuhan esteem (kompetensi, kekuatan, dan kepercayaan diri) ketimbang kebutuhan prestise (penghargaan, status, eksistensi dan apresiasi). Fakta itu mensinyalir bahwa secara ilmiah dan alamiah kebutuhan wajib dan kebutuhan dasar dapat dikaji dan dirumuskan bagian-bagian dan tingkatannya oleh para ahli ketika dalam konteks normal. Namun, disisi lain, dalam kondisi tertentu tidak bisa dikatakan mutlak seseorang mempunyai tingkatan kebutuhan tertentu melainkan individu itu sendiri yang mengetahui kebutuhan apa yang dibutuhkan dan diutamakan. Dalam kondisi ini yang menurut penulis letak kealamiahan yang dimiliki oleh manusia yang sifatnya spontanitas muncul dalam setiap individu baik yang lahir dari faktor bawaan maupun faktor lingkungan (kondisi).

\section{Analisis Kebutuhan Anak Usia Dasar dan Implikasinya Terhadap Penyelenggaraan Pendidikan}


Banyak ahli atau para pakar psikologi telah melakukan penelitian dan melahirkan suatu teori terkait dengan kebutuhan-kebutuhan dasar manusia, baik pada saat dalam masa prenatal, masa kelahiran, masa anak-anak, masa remaja, masa dewasa dan tua. Seperti, Abraham Lincoln, Thomas Jefferson, Albert Einstein, Piaget, Sigmund preud dan lain-lain. Namun, dalam pembahasan ini, fokus kajian yang dideskripsikan oleh penulis yaitu teori Maslow tentang kebutuhan-kebutuhan dasar manusia. Nama "Maslow" tentu sangat tidak asing dan sangat akrab dengan teori kebutuhan dasar manusia.

Pada dasarnya, kebutuhan menurut Maslow, suatu sifat dipandang sebagai kebutuhan dasar jika memenuhi syarat-syarat sebagai berikut :

a. Ketidakhadirannya menimbulkan penyakit;

b. Kehadirannya mencegah timbulnya penyakit;

c. Pemulihannya menyembuhkan penyakit;

d. Pada situasi-situasi tertentu yang sangat kompleks, dimana orang bebas memilih, orang yang sedang berkekurangan ternyata mengutamakan kebutuhan itu dibandingkan jenis-jenis kepuasan lainnya; dan

e. Kebutuhan itu tidak aktif, lemah, atau secara fungsional tidak terdapat pada orang sehat (Mif, 2008, 192).

Meski pendapat tersebut dapat dipahami, akan tetapi masih banyak lagi penjelasan Maslow dalam mendefiniskan kebutuhan dasar khususnya terkait dengan dorongan manusia. Setiap individu juga didorong oleh kebutuhan-kebutuhan yang universal yang dibawa sejak lahir yang tersusun dalam satu tingkat dari yang paling kuat/utama hingga yang paling lemah/rendah. Sebab, manusia memiliki kemerdakaan dan keparipurnaan dalam mengaktualisasikan dirinya dengan lingkungan.

Sebagaimana telah disinggung diatas, secara komprehensif setiap individu mempunyai kebutuhan-kebutuhan dasar yang sama meskipun berbeda tingkatan usia. Karena kebutuhan dasar merupakan aspek yang mesti dimiliki dan dipenuhi oleh manusia untuk bisa bertahan hidup dan menmperoleh kebahagian. Hanya saja yang membedakan antara kebutuhan orang dewasa dengan anak usia dasar yaitu pada tingkat kebutuhan atau levelnya. Perbedaan-perbedaan level kebutuhan tersebut bukan berarti tidak beralasan, perbedaan tersebut dapat terjadi dari segi perbedaan usia, fisik, psikologi, faktor keturunan dan lingkungan.

Pembahasan mengenai kebutuhan dasar pada anak usia dasar tentu tidak terlepas dari pada perkembangan psikologi anak. Anak usia dasar memiliki bentang usia mulai dari 6-12 tahun. Menurut Erik Erikson, "dalam teori perkembangan, usia 610 tahun berada dalam masa pertengahan dan akhir kanak-kanak dan usia 10-12 tahun berada dalam masa remaja" (King, 2014, 168). Kebutuhan-kebutuhan yang harus dimiliki oleh anak tentu menyesuaikan pada taraf perkembangnnya yang meliputi perkembangan fisik, kepribadian, kognitif dan sosial-emosional.

Kebutuhan-kebutuhan anak usia dasar yang mesti terpenuhi tentu lebih banyak memerlukan bantuan dari orang lain (Orang tua, kakak, adik, nenek, kakek, guru, teman dan lainnya) ketimbang dari hasil usaha secara personal. Mengingat pada usia dasar, anak memiliki kekuatan dan kemampuan yang masih terbatas. Oleh sebab itu, sebagai pihak eksternal, orang tua, seorang guru dan sebagai orang yang lebih dewasa perlu mengetahui dan memahami jenis dan tingkat kebutuhan peserta didik yang dalam hal ini anak usia dasar. Termasuk kebutuhan rasa ingin tahu atau kebutuhan belajar yang dapat dipahami pada perinsipnya merupakan manifestasi pemenuhan kebutuhan- 
kebutuhan anak. Tujuannya, supaya dapat dengan mudah membantu memenuhi kebutuhan dasar anak sesuai dengan taraf perkembangannya, baik di lingkungan keluarga, di sekolah (kegiatan belajar mengajar) dan di lingkungan masyarakat.

Terkait dengan teori kebutuhan dasar, Maslow membangun suatu teori yang dikenal dengan hierarki kebutuhan "hierarchy of need". Teori hierarki kebutuhan dasar, terdapat lima tingkatan, yaitu : kebutuhan fisiologis, kebutuhan akan rasa aman dan perlindungan, kebutuhan akan rasa kasih sayang dan memiliki, kebutuhan akan penghargaan (harga diri) dan kebutuhan akan aktualisasi diri (King, 2014). Berdasarkan hasil analisis, berikut ini dideskripsikan kebutuhan-kebutuhan anak usia dasar dan implikasinya dalam pendidikan :

\section{a. Kebutuhan-kebutuhan fisiologis (Pysiological Needs)}

Kebutuhan yang paling dasar dan paling kuat diantara sekian banyak kebutuhan manusia adalah kebutuhan untuk mempertahankan hidupnya secara fisik. Kebutuhan fisiologis adalah sejumlah kebutuhan yang paling mendesak dan menjadi prioritas utama dalam pemenuhannya karena berkaitan dengan kelangsungan hidup dan kondisi fisik anak. Sebagaimana dalam Islam, manusia dalam konsep al-Basyr yaitu sebagai mahluk yang memiliki unsur biologis yang membutuhkan makanan dan minuman dapat bertahan hidup (Muallimin, 2017). Kebutuhan fisiologis meliputi oksigen untuk bernafas, makanan, minuman, sandang, tempat tinggal, seks, tidur, buang air besar atau air kecil, menghindari bahaya dan penyakit, istirahat dan lain-lain. Manusia yang lapar akan selalu termotivasi untuk makan, bukan untuk melakukan hal lain, meskipun secara nyata masih merasakan kebutuhan akan kasih sayang, rasa nyaman dan kebutuhan lainnya. Manusia akan mengabaikan semua kebutuhan lain sampai kebutuhan fisiologisnya terpenuhi dan terpuaskan. Maka, jelas bahwa kebutuhan dasar fisiologis ini merupakan kebutuhan terkuat dari semua kebutuhan.

Pada kondisi normal, anak usia dasar, kebutuhan akan makanan dan minuman tidak sebanyak sebagaimana kebutuhan orang dewasa. Anak pada usia (6-10 tahun ) cenderung makan dan minum dengan ukuran yang sedikit, berkisar sepertiga dari ukuran makanan orang dewasa, karena kapasitas lambung dan usus mereka masih terbatas. Begitu juga ketika anak-anak menginjak usia yang lebih tua (10-12) yang dibarengi dengan pertumbuhan fisik yang lebih besar, maka ukuran makanan yang dibutuhkan semakin banyak, karena energi yang dibutuhkan semakin tinggi. Menurut Eillen ukuran fisik anak usia dasar (6-12 tahun) dinyatakan pada table berikut :

Tabel 1

\begin{tabular}{|c|c|c|c|}
\hline Usia & $\begin{array}{c}\text { Berat badan } \\
(\mathrm{Kg})\end{array}$ & $\begin{array}{l}\text { Tinggi Badan } \\
\text { (cm) }\end{array}$ & $\begin{array}{c}\text { Kebutuhan } \\
\text { Energi }\end{array}$ \\
\hline 6 Tahun & $17,3-20,5$ & $106,7-116,8$ & \multirow{5}{*}{$>18000 \mathrm{k} /$ Hari } \\
\hline 7 Tahun & $22,7-25$ & $115-124$ & \\
\hline 8 Tahun & $25-27,7$ & $120-130$ & \\
\hline 9-10 Tahun & $27,72-30,42$ & $130-150$ & \\
\hline 11-12 Tahun & $36,79-39,49$ & $138,75-158,7$ & \\
\hline
\end{tabular}


Ukuran fisik anak usia dasar yang dipaparkan pada tabel diatas bukan berarti ukuran yang mutlak, ukuran tersebut merupakan ukuran secara umum pertumbuhan fisik anak usia dasar. Pertumbuhan fisik anak ada yang cepat dan ada juga yang lambat. Pertumbuhan fisik anak laki-laki umumnya lebih cepat dari pertumbuhan fisik anak perempuan.. Pertumbuhan fisiologis ditandai dengan adanya perubahan-perubahan secara kuantitatif, kualitatif, dan fungsional dari sistem-sistem kerja hayati seperti kontraksi otot, peredaran darah dan pernafasan, persyaratan, sekresi kelenjar dan pencernaan (Yudrik, 2011). Namun, pada umumnya pertumbuhan anak usia dasar berjalan stabil apabila tidak memiliki penyakit atau kelainan fisik.

Ukuran fisik anak sangat berkaitan dengan banyak atau sedikitnya kebutuhan makanan dan minuman anak. Akan tetapi, banyak terjadi kasus anakanak sulit untuk makan nasi secara rutin dan sayur-sayuran, apalagi sayur-sayuran yang mengandung rasa pahit (sawi, pare dan sebagainya). Anak lebih suka mengkonsumsi makanan yang manis, lembut, gurih, asin dan asam. Kita bisa melihat kondisi ril, dimana anak sangat suka mengkonsumsi makanan ringan (snack) yang ada di warung-warung dan makanan siap saji seperti ciki, sari manis, roti, sosis, permen, eskrim dan sebagainya yang justru mengandung banyak bahan kimia yang sangat berbahaya bagi tubuh. Fakta tersebut dapat terjadi, ketika orang tua tidak serius mengasuh anak agar membiasakan diri mengkonsumsi makanan yang alami (sayur masyur, lauk pauk dan buah-buahan) sejak dini yang sangat baik untuk kesehatan tubuh anak.

Pada usia dasar, kebutuhan asupan protein, vitamin, gizi, karbohidrat dan sebagainya merupakan kebutuhan yang sangat penting. Mengingat, pada usia tersebut merupakan usia yang sangat tepat untuk membentuk kecerdasan otak dan ketahanan fisik yang sehat dan kuat. Perkembangan otak pada usia ini sangat baik ketika diberikan asupan makanan yang mengandung banyak protein seperti telur dan daging yang sangat berpengaruh terhadap perkembangan kogitif (kecerdasan) anak. Sebagaimana dalam suatu penelitian disimpulkan bahwa status gizi anak memiliki hubungan yang signifikan terhadap kemampuan kognitif dan anak yang mengalami stunted memiliki risiko 9,226 kali lebih besar untuk memiliki nilai IQ total di bawah rata-rata (Gamayanti, 2011). Begitu juga dengan kebutuhan makanan yang mengandung kalsium yang sangat penting bagi pertumbuhan fisik supaya cepat tinggi dan memiliki otot dan tulang yang kuat.

Pertumbuhan fisik tidak serta merta dipengaruhi oleh faktor makanan, tetapi juga dipengaruhi oleh faktor sifat jasmaniah (genetika), kematangan, kesehatan dan stimulasi lingkungan (Muhammad, 2014). Misalnya, anak-anak yang orang tuanya memiliki postur tinggi, sangat memungkinkan pertumbuhan fisik anak akan cepat tinggi. Begitu juga dengan fisik orang Eropa dan Timur Tengah lebih tinggi dan besar dibandingkan dengan fisik orang asia termasuk orang Indonesia. Pada kondisi normal, Anak yang mendapatkan asupan gizi, vitamin, protein, karbohidrat dan kalsium yang banyak akan lebih sehat, lebih cerdas dan lebih cepat pertumbuhannya, kecuali dengan anak yang membawa faktor gen (keturunan).

Kebutuhan fisiologis anak usia dasar yang mesti terpenuhi selain dari pada makanan dan minuman yaitu kebutuhan sandang seperti baju, celana, perlatan mandi dan peralatan sekolah. Kebutuhan fisiologis berkaitan dengan pendidikan seseorang, dalam suatu teori kebutuhan dasar psiko-logis, Niemic \& Riyan (2009) menjelaskan bahwa pemenuhan kepuasan kebutuhan dasar psikologis berkaitan 
dengan aktif atau pasifnya individu dalam belajar (Alsa, 2016). Teori ini mengemukakan bahwa seseorang dapat mengikuti proses pendidikan (kegiatan belajar mengajar) dengan baik apabila kebutuhan fisiologis sudah terpenuhi. Misalnya, anak usia membutuhkan wahana bermain dan berolahraga yang sesuai dengan taraf perkembangannya, baik di rumah maupun di sekolah.

Pada usia dasar, anak berada pada fase yang sangat suka dengan aktivitas bermain dan sangat suka bergerak. Anak harus disediakan fasilitas bermain supaya merasa senang dan bahagia untuk mengekspresikan keinginannya. Fakta ini juga yang menjadi dasar bahwa pentingnya model pembelajaran berbasis game sebagai upaya untuk membuat anak merasa senang dan nyaman dalam mengikuti kegiatan belajar mengajar. Guru tidak hanya mengajar dengan model formal saja melainkan pembelajaran harus diwarnai dengan permainan-permainan yang bermuatan edukasi, agar anak tidak merasa bosan dan jenuh. Ketika anak-anak merasa bosan dalam mengikuti pembelajaran, maka secara otomatis minat belajar anak akan menurun yang kemudian akan berdampak terhadap pencapaian hasil belajar yang tidak maksimal.

Kebutuhan wahana permainan juga sangat menyokong pertumbuhan kekuatan tulang dan otot anak. Ketika anak kurang bermain dan berolahraga, maka dampaknya anak cenderung terlihat tidak bahagia dan tidak jarang juga rentan terkena penyakit. Selanjutnya, anak juga membutuhkan waktu untuk istirahat yang cukup. Anak usia dasar cenderung cepat merasa lelah dalam bergerak maupun berfikir dan juga cepat mengantuk. Fakta ini yang menjadi dasar mengapa jam belajar anak sekolah dasar kelas 1 lebih pendek dari kelas 2, kelas 2 lebih pendek dari kelas 3 dan seterusnya bahkan sangat jauh berbeda dengan jam belajar anak SMP dan SMA. Begitu juga dengan jam istrirahatnya, semakin dini usia anak maka semakin memerlukan banyak waktu untuk istirahat, karena itu sudah merupakan kebutuhan fisik yang alamiah bagi anak.

\section{b. Kebutuhan akan rasa aman dan perlindungan (Need for self-security and security)}

Kebutuhan akan rasa aman dan perlindungan juga termasuk dalam kebutuhan dasar yang berada pada level kedua setelah fisiologis. Kebutuhan ini cenderung mendorong manusia untuk memperoleh kenyamanan, ketentraman hidup dan terjaga dari lingkungannya, seperti mendapat jaminan keamanan dan terlindungi dari marabahaya serta kebebasan dari daya-daya mengancam seperti kriminalitas, perang, terorisme, penyakit, takut, cemas, bahaya, kerusuhan dan bencana. Seseorang yang tidak mendapatkan rasa aman dan perlindungan tentu akan selalu merasa resah, gelisah, takut dan bahkan dapat berakibat lebih fatal seperti stres dan gila.

Pada usia dasar, anak akan merasa aman yang cukup apabila berada dalam ikatan keluarga yang kuat dan harmoni begitu juga sebaliknya, apabila ikatan keluarga lemah, maka anak akan merasa cemas, gelisah, tidak tentram, setres, dan kurang percaya diri (Muhammad, 2004). Perkembangan keperibadian anak berkaitan dengan pola asuh orang tua, termasuk memberikan rasa aman kepada anak. Suatu penelitian membutikan bahwa pola asuh orang tua berpengaruh positif terhadap kepribadian anak (Inikah, 2015). Oleh sebab itu, peran orang tua atau keluarga sangat dibutuhkan dalam memenuhi dan menjamin rasa aman anak agar memperoleh ketentraman, kepastian dan keteraturan lingkungannya. 
Kebutuhan rasa aman anak usia dasar dapat dipenuhi dengan cara memberikan perhatian yang penuh, menciptakan lingkungan keluarga, sekolah dan masyarakat yang tentram, jauh dari konflik (perkelahian dan peperangan) dan membatasi ruang bermain anak dari tempat yang berbahaya bagi fisik anak. Jika kebutuhan rasa aman tidak terpenuhi, tentu berdampak bahaya terhadap psikologi anak (mental dan sikap), misalnya anak yang berada di wilayah konflik sosial tentu akan mengalami stres, rasa takut yang berlebihan dan tarauma yang sangat berbahaya dan dapat menjadi penghambat masa depan anak.

Semakin dini anak usia dasar maka semakin membutuhkan perlindungan dan rasa aman dari orang lain (orang tua dan orang dewasa). Begitupun sebaliknya, semakin bertambah usia anak, maka akan semakin bisa berfkir tentang yang baik, buruk, bahaya dan tidaknya segala sesuatu di sekitarnya serta rasa keberaniannya juga semakin tinggi. Misalnya, anak usia 6-8 tahun masih membutuhkan pendampingan orang tua ketika berangkat ke sekolah, berbeda dengan anak usia 912 tahun yang sudah bisa berangkat ke sekolah sendiri. Kebutuhan rasa aman anak mesti terpenuhi dimanapun tempatnya termasuk di sekolah dan di lingkungan masyarakat. Pentingnya rasa aman terhadap anak usia dasar diperkuat dengan sejumlah hasil penelitian yang membuktikan bahwa rasa aman di sekolah sangat penting bagi keberhasilan belajar peserta didik.

Rutter et al (1979) mencatat bahwa capaian tingkah laku dan akademis anak cenderung baik ketika kondisi sekolah bersih dan memiliki dekorasi yang bagus (Alsa, 2016). Artinya bahwa peran pihak sekolah atau guru sama pentingnya seperti peran keluarga (orang tua) untuk memberikan rasa aman terhadap anak. Setiap anak mendambakan suasana sekolah (ruang kelas, perpustakaan, ruang bermain dan ruangan lainnya) yang nyaman, bersih, asri dan terhindar dari kebisingan atau situasi yang mengancam. Tersedianya Unit Kesehatan Sekolah (UKS) juga sangat berperan untuk memenuhi kebutuhan anak ketika mengalami sakit. Kehilangan rasa aman di sekolah dapat berdampak terhadap proses belajar, seperti anak menjadi tidak fokus, jenuh dan hilangnya semangat belajar yang kesemuanya itu berpengaruh terhadap hasil belajar anak.

\section{c. Kebutuhan akan rasa kasih sayang dan memiliki (Need for Love and belongingness)}

Ketika kebutuhan fisiologis dan rasa aman sudah terpenuhi, maka rasa kasih sayang akan muncul dalam diri seseorang, merasa butuh rasa kasih sayang dari seorang teman, sahabat dekat, dan kekasih. Kebutuhan ini yang mendorong individu untuk melakukan atau mengadakan hubungan afeksi (hubungan emosional) dengan orang lain yang diaktualisasikan dalam bentuk kebutuhan akan rasa memiliki dan dimiliki, mencintai dan dicintai, kebutuhan akan rasa diakui dan diikutsertakan sebagai bagian dari suatu kelompok, merasa dirinya penting, rasa setia kawan, kerjasama dan sebagainya.

Pada anak usia dasar, anak masih berada pada masa yang pubertas dimana sangat ingin diperhatikan, diberi perhatian dan disayang. Kendati anak-anak melakukan kesalahan, mereka cenderung tidak ingin disalahkan, bahkan akan kembali marah, kesal dan menangis apabila terus menerus disalahkan. Sikap agresi (rasa kesal, kecewa dan frustasi) masih sangat tinggi khususnya pada anak yang berusia 6-8 tahun. Pada usia ini, anak tidak ingin disalahkan, anak cenderung menampilkan perilaku menyerang (membentak, memukul, menggigit dan sebagainya) terhadap orang yang mengganngunya. Berbeda dengan anak usia 9-10 
tahun yang sudah bisa menunjukan benar atau salahnya suatu perbuatan dan pada anak usia 12 tahun ke atas yang sudah memiliki pandangan yang kompleks dan teratur tentang dirinya (Makmun, 2006). Akan tetapi, umumnya anak usia dasar masih sangat sensitif terhadap segala sesuatu yang mengganggu dirinya dan sangat suka untuk dipuji, disanjung, dan dibanggakan oleh orang terdekatnya (orang tua dan teman). Sehingga, orang tua dan orang dewasa mesti paham memperlakukan mereka dan sabar dalam menghadapi perilkunya.

Kebutuhan rasa kasih sayang pada anak usia dasar dapat dilakukan dengan cara memberikan perhatian penuh kepada mereka, misalnya menyediakan sarapan atau bekal makanan, menemani anak ketika belajar, mengajak mereka berwisata (refreshing), bermain, bersanda gurau, membelikan mereka makanan, mainan atau benda-benda yang mereka sukai. Selain dari pada itu, di lingkungan sekolah, anakanak sangat merasa senang dan berperliku lebih positif ketika segala bentuk perbuatan dan usaha mereka diapresiasi. Misalnya, anak-anak diberi reward (hadiah) ketika mereka berhasil melakukan sesuatu hal. Sebaliknya, anak akan berprilaku negatif dan hilang kepercayaan diri apabila merasa diremehkan, dikucilkan dan merasa terisolasi dari orang-orang disekitarnya. Seorang guru dapat melakukan berapa upaya untuk menumbuhkan rasa berharga dalam diri anak, seperti menghargai pendapat anak, memuji hasil karyanya, menegur dengan bahasa yang halus ketika mengingatkan seorang anak yang berbuat salah, melengkapi kekurangannya dan memberi motivasi secara terus menerus.

Jika kebutuhan rasa kasih sayang tidak terpenuhi oleh orang tua, maka sikap dan kepribadian anak akan mengalami kekurangan dan berpengaruh terhadap mental dan perilaku sosial anak. Interaksi yang buruk antara orang tua dan anak sangat berpengaruh dalam membentuk cara pandang anak terhadap kehidupannya, anak usia dasar usia 6-8 tahun seringkali meniru perilaku orang tuanya (stimulus). Tatkala orang tua berperilaku buruk (berbicara kasar dan marah) maka anak juga akan meniru dan melakukan hal yang sama. Akibatnya, anak akan berani melawan nasehat orang tua. Sebagaimana yang terjadi di daerah perkotaan, banyak anakanak yang kurang mendapat perhatian dari orang tuanya karena sibuk bekerja, sehingga tidak ada waktu untuk mendidik anak. Dampaknya, Anak-anak akan terbiasa hidup sendiri, bebas, dan tidak peduli dengan orang tuanya dan tidak jarang terkena pergaulan bebas yang pada gilirannya membuat harapan masa depan anak pupus. Oleh karenanya, hidup tanpa cinta dan kasih sayang dapat memungkinkan menjadi hambatan proses pertumbuhan dan perkembangan anak.

\section{d. Kebutuhan akan rasa harga diri (Need for self-esteem)}

Kebutuhan akan rasa harga diri merupakan suatu kebutuhan seseorang untuk dapat menumbuhkan rasa percaya diri dimana ia merasa memiliki kapasitas, kredibilitas dan merasa berharga. Maslow membagi kebutuhan akan rasa penghargaan menjadi dua jenis yaitu, pertama kebutuhan akan self-respect atau penghormatan/penghargaan dari diri sendiri, seperti percaya diri, hasrat untuk memiliki kompetensi, kekuatan pribadi, edukasi dan kemandirian. Kedua yaitu esteem kebutuhan akan pernghargaan dari orang lain atas apa yang telah dilakukan, berupa pengakuan, penerimaan, perhatian, kedudukan atau status, pangkat, nama baik dan sebagainya.

Setiap individu membutuhkan pengakuan orang lain akan kemampuan dan nilai-nilai yang dimilikinya, termasuk anak usia dasar. Anak usia dasar sangat suka diberi pujian atas segala sesuatu yang mereka kerjakan. Anak akan merasa senang 
dan bangga ketika mendapatkan suatu penghargaan seperti pujian, hadiah dan dipandang hebat oleh orang lain (orang tua, guru, teman dan sebagainya). Anak sangat suka diakui keberadaannya di tengah-tengah orang banyak. Seorang anak yang memiliki cukup harga diri akan merasa lebih percaya diri, aktif, progresif dan lebih produktif. Misalnya, ketika di kelas, jika salah satu anak diberi apresiasi dan disanjung dengan kata-kata seperti hebat, pintar dan rajin di depan temantemannya, maka anak tersebut akan semakin percaya diri dan bangga dengan dirinya.

Anak usia dasar sangat sensitif, mereka akan kesal dan mentalnya akan menurun ketika hasil usaha atau pekerjaan mereka tidak dihargai terlebih dinilai buruk. Rasa malu akan terus menerus menyelimuti dirinya, sehingga tidak jarang seorang anak akan merasa minder dari teman-temannya. Oleh sebab itu, sebagai orang tua maupun orang dewasa yang dekat dengan anak mesti pandai memberikan penghargaan untuk meumbuhkan rasa percaya diri anak. Sebab, ketika anak usia dasar kehilangan percaya diri, maka akan berdampak terhadap psikologinya, cenderung menutup diri, rasa tidak berdaya, merasa malu, kehilangan semangat atau gairah hidup dan dapat menimbulkan rasa putus asa, merasa tidak bisa apa-apa yang pada akhirnya merusak mental anak.

\section{e. Kebutuhan akan aktualisasi diri (Need for self-actualization)}

Kebutuhan aktualisasi diri adalah kebutuhan untuk memenuhi dorongan hakiki manusia untuk menjadi orang yang sesuai dengan keinginan dan potensi dirinya. Kebutuhan ini memberikan kecenderungan individu untuk berjuang melakukan apa saja dalam meraih sebuah harapan. Aktualisasi diri menjadi suatu kebutuhan yang mendorong individu untuk membuktikan dan menunjukan dirinya kepada orang lain. Pada tahap ini, seseorang semaksimal mungkin mengembangkan segala kemampuan, kapasitas dan potensi yang dimilikinya.

Kebutuhan aktualisasi diri menjadi suatu kebutuhan yang paling tinggi. Meskipun kebutuhan-kebutuhan dalam tingkatan sebelumnya sudah terpuaskan, namun kebutuhan akan aktualisasi diri gagal diwujudkan maka bukan tidak mungkin akan menyebabkan pribadi seseorang merasa kecewa, tidak tenang, tidak puas, bahkan dapat dikatakan dalam keadaan tidak sehat secara psikologis. Aktualisasi sebagai tujuan final-ideal hanya dapat dicapai oleh sebagian kecil dari populasi, itupun hanya dalam presentase yang kecil. Menurut Maslow "rata-rata kebutuhan aktualiasasi diri hanya terpuaskan 10\%" (Alwisol, 2009, 209). Ada beberapa faktor penyebab mengapa kebutuhan aktualisasi diri jarang terpenuhi yaitu terjadi ketika seseorang kesulitan untuk menyeimbangkan antara suatu kebanggaan dengan kerendahan hati, antara kemampuan memimpin dengan tanggung jawab yang harus diemban, merasa takut lemah dan merasa tidak mampu.

Kebutuhan akualisasi diri pada anak usia dasar masih bersifat ringan dan sederhana. Pada usia tersebut, anak sangat gemar menampilkan kemampuan ( $s k i l l$ ) yang mereka miliki di depan orang lain. Anak sering kali melakukan suatu tindakan sesuai dengan kehendak mereka dan mengekspresikan diri secara bebas. Pada usia 6-9 tahun, anak sangat cepat tertarik dengan sesuatu yang unik dan menyenangkan. Ego mereka masih sangat tinggi, mereka tidak bisa dipaksa untuk melakukan sesuatu yang tidak mereka sukai dan pola pikir anak belum bisa mempertimbangkan sesuatu secara matang, apakah sesuatu itu berdampak baik, berbahaya, merugikan dan sebagainya. Misalnya, ketika hujan, anak-anak melihat orang-orang sedang mandi hujan, maka mereka akan cepat teratrik dan 
memaksakan diri untuk mandi meskipun dalam keadaan yang kurang sehat. Ketika ia dilarang, mereka akan melakukan berbagai macam cara, seperti menangis bahkan mengamuk, agar tetap diizinkan. Begitu juga di waktu belajar, ketika anak ribut atau berdebat dengan temannya, maka akan sangat sulit untuk didiamkan dan ketika diam, itupun hanya dengan durasi waktu yang singkat, kemudian anak akan kembali mengulangi kejadian yang sama.

Berbeda dengan anak yang berusia 10-12 tahun, pada usia kemampuan anak membedakan sesuatu yang baik atau buruk semakin baik. Anak sudah lebih berhati-hati dalam melakukan suatu tindakan meskipun ego mereka masih sangat tinggi. Misalnya, anak sudah bisa menuruti intruksi orang tua atau guru dan sudah bisa menerima nasehat dengan baik. Pada usia ini, anak mulai menampilkan kelebihan yang mereka miliki, seperti bermain bola, menari, bernyanyi dan sebagainya. Anak banyak meluangkan waktunya untuk bermain dan mengekspresikan hobi mereka, karena dengan cara tersebut anak akan mendapatkan kesenangan dan kebanggaan bahwa dirinya memiliki kehebatan yang tidak dimiliki orang lain.

Aktualisasi diri anak usia dasar sangat dipengaruhi oleh faktor eksternal (lingkungan), ketika mereka melihat seseorang bisa bernyanyi, maka mereka akan berupaya menampilkan bahwa mereka juga bisa menyanyi. Selain dari faktor lingkungan, kebutuhan aktualisasi diri anak usia dasar juga dipengaruhi oleh faktor keturunan (bawaan) atau bakat yang mereka bawa sejak lahir, misalnya jika orang tuanya penyanyi, maka anak juga akan mengaktualisasikan dirinya dengan cara bernyanyi, begitu juga ketika orang tuanya pemain bola, maka seorang anak akan mengekspresikan kemampuan dirinya dengan bermain bola. Anak selalu ingin menyaingi kemampuan orang lain dan ingin dianggap seseorang yang hebat. Akan tetapi, aktualisasi diri anak usia dasar masih membutuhkan arahan dan pengawasan dari pihak lain seperti orang tua, guru dan pelatih yang akan membimbing mereka.

Ekspresi anak tidak bisa dipaksakan atau diatur sedemikan rupa, mereka cenderung bebas berekspresi sesuai dengan apa yang mereka sukai dan sulit untuk dilarang. Jika seorang anak dilarang melakukan sesuatu dengan paksaan, maka akan membuat anak marah dan frustasi yang akan berdampak terhadap kerusakan mental anak. Oleh karenanya, sebagai orang tua, guru dan orang dewasa mesti mengenal dan memahami kepribadian, bakat dan keterampilan yang dimiliki anak serta memberikan kebebasan berekspesi kepada anak tanpa mengkesampingkan batas normal, kewajaran, dan tidak membahayakan. Pemahaman terhadap bakat anak juga dapat membantu orang tua dan guru dalam menyusun program pembinaan anak, seperti memfasilitasi hobi anak, benda-benda yang disenangi, kegiatan-kegiatan individu yang disenangi dan membantu mewujudkan masa depan anak yang berprestasi.

Pada proses pendidikan di sekolah, anak membutuhkan wadah untuk menyalurkan bakatnya, sehingga sudah semestinya setiap sekolah dasar (SD/MI) menyediakan kegiatan ekstrakurikuler. Menggiatkan kegiatan-kegiatan ekstrakurikuler yang menyesuaikan bakat anak sangat membantu dalam proses peningkatan keahlian (skill) sejak dini yang pada gilirannya dapat menghantarkan mereka meraih prestasi. Dengan demikian, lembaga sekolah tidak hanya berperan dan berfungsi sebagai wadah untuk memberikan pengetahuan secara kognitif yang bersifat abstrak saja, melainkan benar-benar menjadi lembaga yang berfungsi 
sebagai media pengembangan dan pembinaan minat, bakat dan keterampilan anak dalam rangka menyiapkan diri anak untuk mencapai tujuan atau cita-cita hidupnya.

Selain dari pada lima kebutuhan dasar yang telah dipaparkan di atas, menurut penulis, anak usia dasar juga memiliki kebutuhan akan rasa sukses. Anak usia dasar memiliki keinginan dan target dari segala sesuatu yang mereka lakukan agar berbuah prestasi terutama dalam bidang akademis, bakat dan kreatifitas. Anak memiliki persaan khawatir apabila segala sesuatu yang mereka lakukan tidak mendapatkan hasil yang memukau. Anak cenderung menjauhi kejadian-kejadian yang membuat mereka malu atau rendah dimata orang lain. Pada ranah pendidikan misalnya, anak akan merasa senang dan puas apabila pekerjaan yang dilakukannya berhasil dan berbuah prestasi dan merasa kecewa apabila tidak berhasil. Hal tersebut menjadi bukti bahwa rasa sukses merupakan salah satu kebutuhan pokok peserta didik. Sehingga, seyogyanya orang tua dan guru harus mampu mendidik dan mendorong anak untuk mencapai keberhasilan dan prestasi yang tinggi, sesuai dengan apa yang mereka cita-citakan. Orang tua maupun guru mesti memberikan penghargaan setinggi-tingginya terhadap pencapaian prestasi anak meskipun hanya bernilai standar atau bahkan ketika anak memperoleh kegagalan. Sebagai orang tua atau guru harus menghindari perkataan yang kasar dan bernada negatif atau menampakkan sikap tidak puas terhadap anak yang gagal karena dapat mengakibatkan anak kehilangan percaya diri, merasa tidak berharga dan putus asa.

\section{SIMPULAN}

Aspek-aspek kebutuhan anak usia dasar secara umum tidak berbeda dengan orang dewasa, hanya saja yang membedakannya yaitu pada tingkat kebutuhan atau levelnya. Kebutuhan-kebutuhan anak usia dasar yang harus terpenuhi tentu lebih banyak memerlukan bantuan dari orang lain (Orang tua, kakak, adik, nenek, kakek, guru, teman dan lainnya). Mengingat pada usia dasar, mereka memiliki keterbatasan fisik, pola pikir (abstrak dan operasional konkrit) dan kemampuan motorik yang terbatas. Anak usia dasar juga memiliki sifat yang egois, keras kepala, manja dan sesnsitif yang masih sangat tinggi. Oleh sebab itu, sebagai pihak eksternal, khususnya orang tua dan guru, perlu mengenal, mengetahui, dan memahami jenis dan tingkat kebutuhan peserta didik yang dalam hal ini anak usia dasar.

Pemahaman tentang kebutuhan anak usia dasar sangat berimplikasi terhadap proses pendidikan, baik di rumah maupun di sekolah. Orang tua maupun guru dapat memberikan pembelajaran yang sesuai dengan taraf kebutuhan peserta didik. Sehingga, dengan cara demikian, tidak akan terjadi suatu rasa ketidaktahuan, kebingungan, dan rasa keanehan ketika melihat sikap atau tingkah laku peserta didik. Pasalnya, ketika guru maupun orang tua tidak memahami kebutuhan anak, maka akan akan rentan terjadi sesuatu yang membahayakan seperti perilaku tindak kekerasan terhadap anak di lingkungan keluarga maupun di lembaga pendidikan yang dapat membuat anak setres, frustasi, terkena gangguan mental, dan lain sebagainya yang dapat menjadi hambatan bagi masa depan anak. 


\section{E. DAFTAR PUSTAKA}

Alsa, A., \& Yunus St. N. (2016). Peranan Kepuasan Kebutuhan Dasar Psikologis dan Orientasi Tujuan Mastery Approach terhadap Belajar Berdasar Regulasi Diri, Jurnal Psikologi Volume 43, Nomor 2, 2016: 85 - 106.

Alwisol. (2009). Psikologi Kepribadian, Malang : UMM Press.

Astuti, D., Megawangi, R. \& Sari, M., P., E. 2013. Pengaruh Gaya Pengasuhan Ibu Terhadap Tingkat Kreatifitas Siswa Sekolah Dasar Progresif dan Konvensional di Kota Depok, Badan Penelitian dan pengembagan KEMENDIKBUD, Jurnal Pendidikan dan Kebudayaan, Vol. 19, No. 3, hlm. 365 .

Desmita. (2015). Psikologi Perkembangan, Bandung : PT Remaja Rosdakarya.

Desmita. (2017). Psikologi Perkembangan Peserta Didik, Bandung : Remaja Rosda Karya.

Efendi M. Pengantar Psikopedagogik Anak Berkelainan, Jakarta: PT Bumi Aksara.

Eileen, A. \& Lynn R., M. Profil Perkembangan Anak : Prakelahiran Hingga Usia 12 Tahun.

Feldman, D., R., Old, S.,W., S. \& Papalia, E., D. (2008). Human Dovelopment (Psikologi Perkembagan) : Bagian I s/d IV (A. K. Anwar, Penerjemah). Jakarta : Kencana Prenada Media Group.

Feldman, Old \& Papalia. (2009). Human Development (Briyan Marswendy, Penerjemah). Jakarta : Salemba Humanika.

Feldman, Old \& Papalia. (2010). Human Development, Cet. Ke-2 Jakarta : Prenada Media Group.

Gamayanti, L., I., Sudargo, T. \& Puspitasari, D., F. (2011). Hubungan Antara Status Gizi dan Faktor Sosio Demografi dengan Kemampuan Kognitif Anak Sekolah Dasar Di Daerah Endemis Gaki. Jurnal Gizi Indon, 34 (1) : 52-60.

Gardner \& Calvin S. (1993). Teori-teori Psikodinamik,Yogjakarta : Kanisus.

Hadis A. (2006). Pendidikan Anak Berkebutuhan Khusus (Autistik), Bandung : Alfabeta.

Hadinuto, R., S. \& Monks F.J. (2014). Psikologi Perkembangan, Yogjakarta : UGM Press.

Hurlock B. Elizabeth. (1980). Psikologi Perkembangan Suatu Pendekatan Sepanjang Rentang Hidup, Jakarta : Jakarta Erlangga.

Inikah.S.(2015).Pengaruh Pola Asuh Orang Tua danKecemasanKomunikasi terhadap Kepribadian Peserta Didik. Jurnal Konseling Religi : Bimbingan Konseling Islam, Vol. 6, No.1

Juabdin, H. (2017). Konsep Kebutuhan Dasar Manusia dalam Perspektif Pendidikan Islam, Al-Tadzkiyyah : Jurnal Pendidikan Islam, Vol. 8, Edisi II.

Laura, K., A. (2014). Psikologi Umum, Jakarta : Salemba Humanika. 
Mif, B. 2008. Psikologi Pertumbuhan, Bandung : Rosdakarya.

Muallimin. (2017). Konsep Fitrah Manusia dan Implikasinya dalam Pendidikan Islam, Al-Tadzkiyyah : Jurnal Pendidikan Islam, Vol. 8, Edisi II, hlm. 249266.

Mubayidh, M. (2006). Kecerdasan dan Kesehatan Emosional Anak, Jakarta : Pustaka Al-Kautsar.

Muhammad, A. \& Muhammad, A. (2004). Psikologi Remaja : Perkembangan Peserta Didik, Jakarta : PT Bumi Aksara.

Punney U. (2012). Psikologi Perkmbangan, terj.Noermalasari Fajar Widuri, Jakarta : Penerbit Erlangga.

Rakhmawati I. (2015). Peran Keluarga dalam Pengasuhan Anak. Konseling Religi : Jurnal Bimbingan Konseing Islam, Vol. 6, No.1.

Santrock, W., J. (2007). Perkembangan Anak (Mila Rachmawati dan Anna Kuswanti, Penerjemah). Jakarta : Penerbit Erlangga.

Santrock, W., J. (2011). Perkembangan Anak, terj. Verawaty Pakpahan \& Wahyu Anugraheni, Edisi 11, Jakarta : Salemba Humanika.

Suryabrata S. (2013). Psikologi Kepribadian, Jakarta : PT RajaGrafindo Persada.

Yudrik, J. (2011). Psikologi Perkembangan, Jakarta : Kencana.

Yusuf S. (2017). Psikologi Perkembangan Anak dan Remaja, Bandung : PT Remaja Rosdakarya Offest. 